Article

SANTOS, F.L.S. ${ }^{1 *}$

TEIXEIRA, I.R. ${ }^{2}$

TIMOSSI, P.C. ${ }^{3}$

SILVÉRIO, J.G.D. ${ }^{1}$

BENETT, C.G.S. ${ }^{1}$

\section{Phytosociological Survey of Weed Plants in INTERCROPS OF COMMON BEANS AND CASTOR BEANS}

\author{
Levantamento Fitossociológico de Plantas Daninhas em Lavouras \\ Consorciadas de Feijão Comum e Mamona
}

\begin{abstract}
The aim of this paper was to conduct the phytosociological survey of weeds in cultivated areas with common beans and castor beans in the municipality of Ipameri, in the Southeast region of the State of Goiás, considering intercropping and monoculture. The survey was conducted 20 days after emergence of the crop using the square inventory method. We evaluated the green and dry biomass of weeds, their leaf area, frequencies, density and absolute and relative dominance, relative importance and similarity index, expressed as a percentage. Sixteen weed species were identified, distributed into 10 botanical families. The most important weed species in the Southeast region of Goiás for the cultivation of common beans and castor beans were: Cenchrus echinatus, Euphorbia heterophylla, Alternanthera tenella, Eleusine indica and Urochloa decumbens. The weed community shows a high level of similarity between intercropping and monoculture for castor bean and common bean crops.
\end{abstract}

Keywords: Phaseolus vulgaris, Ricinus communis, intercropping, phytosociology.

RESUMO - Objetivou-se com este trabalho realizar o levantamento fitossociológico de plantas daninhas em área cultivadas com feijão e mamona no município de Ipameri, região sudeste do Estado de Goiás, considerando o cultivo consorciado e o monocultivo das culturas. O levantamento foi realizado 20 dias após a emergência das culturas, pelo método do quadrado inventário. Avaliaram-se a biomassa verde e seca das plantas daninhas, área foliar, frequências, densidade e dominância absoluta e relativa, importância relativa e índice de similaridade, expressos em porcentagem. Foram identificadas 16 espécies de plantas daninhas, distribuídas em dez famílias botânicas. As espécies de plantas daninhas mais importantes na região do sudeste goiano nos cultivos de feijão e mamona foram: Cenchrus echinatus, Euphorbia heterophylla, Alternanthera tenella, Eleusine indica e Urochloa decumbens. A comunidade de plantas daninhas apresenta alto indice de similaridade entre as formas de cultivo consorciado e em monocultivo nas lavouras de mamona e feijão.

Palavras-chave: Phaseolus vulgaris, Ricinus communis, consórcio, fitossociologia.

\section{* Corresponding author: \\ <lourenco_dm@hotmail.com>}

Received: May 18, 2016

Approved: June 30, 2016

Planta Daninha 2017; v35:e017162166

1 Universidade Estadual de Goiás, Ipameri-GO, Brasil; ${ }^{2}$ Universidade Estadual de Goiás, Anápolis-GO, Brasil; ${ }^{3}$ Universidade Federal de Goiás, Jataí-GO, Brasil. 


\section{INTRODUCTION}

An increasing number of researches have prioritized the improvement of techniques aiming at the sustainability of agricultural production systems, seeking to optimize the exploration of natural resources and inputs involved in production. In that sense, intercropping is an interesting alternative, since it allows planting two cultures within the same area, promoting a better use of the area, the inputs and labor, in addition to allowing a gain increase for the farmer (Cunha et al., 2014).

The castor bean culture has been very successfully used in intercropping with short-cycle annual cultures (Corrêa et al., 2006; Teixeira et al., 2012), due to its easy implementation, the capital return to the farmer with the sale of the grains, in addition to the improvement of the chemical characteristics of the soil due to the incorporation of culture residues and fertilizer residues that remain on the soil.

Most of the information in the literature involving the use of castor beans in intercrops has to do with its association to the Vigna unguiculata bean species, whose denominations are: blackeyed bean, cowpea, black-eyed pea, among others. However, this species shows a high level of aggressiveness due to its growth habit and bindweed type (type IV), which may compromise the castor bean yield, as observed on a study by Corrêa et al. (2006). In that aspect, common beans, which belong to the Phaseolus vulgaris species, may be indicated as an adequate alternative for castor bean intercropping, since it is an important element for the food habits of Brazilians, as well as due to the morphophysiological adaptation of the plants to the system, since it is a C3 plant (Vieira, 2006), in addition to being a legume, with the capacity to make the soil richer in terms of nitrogen content through the nitrogen biological fixation process - NBF.

Both cultures show a C3 photosynthetic metabolism, characterized by low photosynthesis efficiency, slow initial growth and little competitiveness in relation to other plants (Azevedo et al., 2007). These characteristics make them very sensitive to the competition with weeds. This sensitivity and the management of weed infestations vary a lot according to the characteristics of the culture regions, with yield losses due to lack of information (Azevedo, et al., 2007; Ferreira et al., 2015). In terms of productivity, the reduction due to the competition with weeds may exceed 80\% (Azevedo et al., 2007), justifying the high costs for farmers in the control of weeds, above all for the common bean culture.

This type of intercrop is used mainly in small properties for food production and income generation, and it may contribute to reduce the weed community, since it promotes a larger area occupation (Fontes et al., 2014). However, one of the main obstacles to expand the castor bean cultivated area, whether on intercrops and/or monocultures, is the issue of weed management, considering the lack of registration of selective herbicides for castor bean cultures, mainly those applied post-emergence aiming at controlling eudicotyledon weeds.

Within that context, the identification of weeds on the crop is the first step to define their adequate management. This process consists in identifying the infesting species and determining their degree of importance, taking into consideration the phytosociological parameters. After this phase, the best management method to be used is defined (Oliveira and Freitas, 2008).

The purpose of this paper was to identify and quantify the floristic composition of weeds in cultivated areas with beans and castor beans in intercrops and monocultures, conducted in the summer crops in the Southeast region of Goiás.

\section{MATERIAL AND METHODS}

The phytosociological survey was conducted in areas under three culture methods: common bean and castor bean intercrop, castor bean monoculture and common bean monoculture, in the municipality of Ipameri, Southeast region of the State of Goiás, for the 2013/2014 and 2014/2015 crops.

The climate of the region is classified as Cwa-Humid Mesothermal climate, with annual rainfall and mean temperature of $1.750 \mathrm{~mm}$ and $25{ }^{\circ} \mathrm{C}$, respectively. The climatic data related to the period in which the experiments were conducted are shown on (Figure 1). 

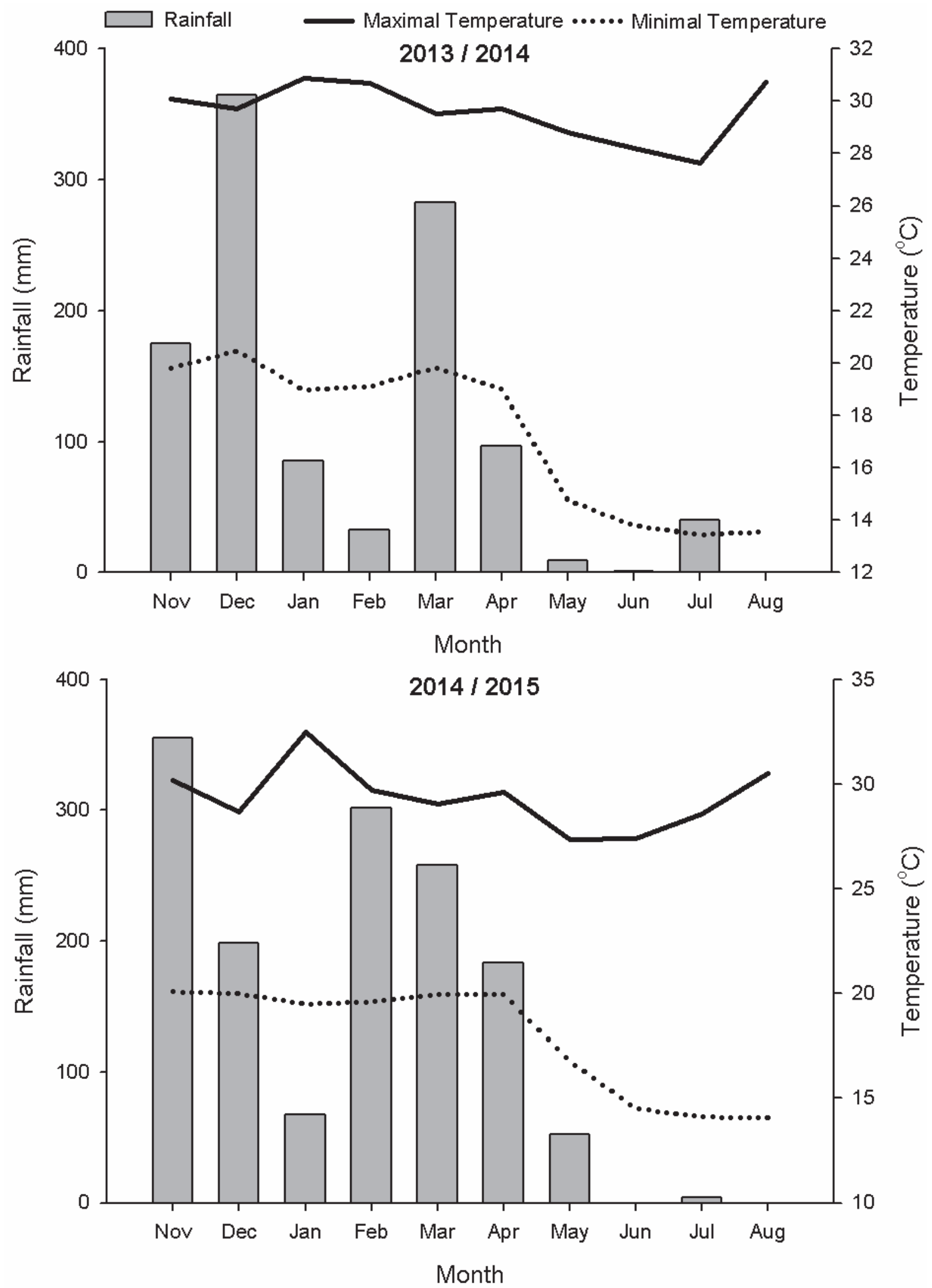

Source: (Data provided by the National Meteorology Institute - INMET-GO).

Figure 1 - Climatic data related to rainfall and maximal and minimal temperatures during the period from November 2013 to August 2015, in Ipameri-GO. 
The soil of the experimental area is classified as deep dystrophic Red Latosol, with adequate drainage.

The soil for the planting of the cultures was prepared using the conventional system, with one plowing and two harrowing preparations before planting the cultures. The sowing of castor beans and common beans was simultaneously and manually conducted on Nov/25 and Nov/20, respectively for the 2013/2014 and 2014/2015 crops. The Pérola bean cultivar was used, from the Pinto bean group, with semi-erect plants, with approximate cycle of 90 days. For the castor bean culture, the BRS Paraguaçú cultivar was used, with high plants, semi-dehiscent fruits and mean approximate cycle of 240 days. For the base fertilization, $400 \mathrm{~kg} \mathrm{ha}^{-1}$ of the NPK 04-30-16 formulation was used.

Samples of 126 plots of $15 \mathrm{~m}^{2}$ each were taken, 20 days after the emergence (DAE) of the cultures, quantifying the weeds using the square inventory method (Braun-Blanquet, 1979), in which a $0.5 \times 0.5 \mathrm{~m}$ square was used, randomly applied three times inside each plot. The species present on each sampled area were cut close to the soil, placed inside paper bags and taken immediately to the laboratory, where they were identified with the help of the specialized literature (Lorenzi, 2014), in addition to consulting experts, whenever necessary. After their identification, the plants were quantified, and the leaf area of each species was measured with a LICOR CI-202 leaf area meter. Afterwards, the fresh biomass was weighted, obtaining the mass by species and the total mass, and they were then taken to the stove at a temperature of $70{ }^{\circ} \mathrm{C}$ for 72 hours, in order to obtain the dry biomass.

In addition to identifying and quantifying the individuals per area, the phytosociological parameters related to the weed community were calculated in both experiments, such as: density, relative density, frequency, relative constancy, relative dominance, importance value index and relative importance, suggested by Mueller-Dombois and Ellenberg (1974), using the methodology described by Monquero et al. (2014). In order to evaluate the similarities between the botanical populations, the Similarity Index (SI) by Sorensen was used, as described by Odum (1985), considering that $\mathrm{SI}=(2 \mathrm{a} / \mathrm{b}+\mathrm{c}) \times 100$, where $\mathrm{a}=$ number of common species to both areas; and $\mathrm{bc}=$ total number of species on both compared areas. SI varies from 0 to 100, and it reaches its maximum peak when all species are common to both areas, and shows its minimal value when no common species occur.

The data related to the weed community were submitted to the descriptive statistical analysis (DSA), on both culture times, in an isolated manner. The Excel software was used to analyze the data.

\section{RESULTS AND DISCUSSION}

\section{Weed diversity in culture systems}

In the evolution of the prevailing weed community, conducted $20 \mathrm{DAE}$, on the common and castor bean intercropping systems and on the respective monocultures, 16 weed species were identified infesting the cultures for the studied crops, distributed into 10 families. The most representative family on the survey was Asteraceae, with four species, followed by Poaceae, with three species; Euphorbiaceae, with two species; and Amaranthaceae, Commelinaceae, Rubiaceae, Malvaceae, Cyperaceae, Phyllantaceae and Convolvulaceae, with one species each (Table 1).

The leaf area readings of the infesting species showed an increase on the leaf area index (LAI) on the second crop on all culture systems (Figure 2). Certainly, the reduced pluviometric rainfall that occurred during the first year (Figure 1) was responsible for the smaller leaf area of the evaluated weeds. According to Pinheiro and Chaves (2011), this reduction is a result of the reduced turgescence of guard cells and stomata. These processes are fundamental for the cellular expansion and the increase of the lead area (Taiz and Zeiger, 2013).

The amount of dry biomass accumulated by weeds was lower on the first culture crop under the intercropping system in comparison to the monocultures. However, for the second crop, this 
Table 1 - Weed mean relationship (botanical family and species) on castor bean and common bean intercropping systems and their respective monocultures, on the 2013/2014 and 2014/2015 crops, in Ipameri-GO. UEG, Ipameri-GO, 2015

\begin{tabular}{|c|c|c|c|c|}
\hline \multicolumn{2}{|r|}{ Weed community } & \multicolumn{3}{|c|}{ Situation } \\
\hline Family & Species & $\mathrm{M}+\mathrm{F}$ con. & M mono & F mono \\
\hline \multirow{3}{*}{ Poaceae } & Cenchrus echinatus L. & $\mathrm{X}$ & $\mathrm{X}$ & $\mathrm{X}$ \\
\hline & Eleusine indica (L.) Gaertn & $\mathrm{X}$ & $\mathrm{X}$ & $\mathrm{X}$ \\
\hline & Urochloa decumbens (Stapf) R.D. Webster & $\mathrm{X}$ & $\mathrm{X}$ & $\mathrm{X}$ \\
\hline \multirow{2}{*}{ Euphorbiaceae } & Euphorbia heterophylla L. & $\mathrm{X}$ & $\mathrm{X}$ & $\mathrm{X}$ \\
\hline & Chamaesyce hirta (L.) Millsp. & $\mathrm{X}$ & $\mathrm{X}$ & $\mathrm{X}$ \\
\hline \multirow{4}{*}{ Asteraceae } & Emilia fosbergii Nicolson & $\mathrm{X}$ & $\mathrm{X}$ & $\mathrm{X}$ \\
\hline & Acanthospermum hispidum DC. & - & $\mathrm{X}$ & - \\
\hline & Tridax procumbens L. & - & - & $\mathrm{X}$ \\
\hline & Bidens pilosa $\mathrm{L}$. & $\mathrm{X}$ & - & - \\
\hline Amaranthaceae & Alternanthera tenella Colla & $\mathrm{X}$ & $\mathrm{X}$ & $\mathrm{X}$ \\
\hline Commelinaceae & Commelina benghalensis L. & $\mathrm{X}$ & $\mathrm{X}$ & $\mathrm{X}$ \\
\hline Rubiaceae & Spermacoce latifolia Aubl & $\mathrm{X}$ & - & $\mathrm{X}$ \\
\hline Malvaceae & Sida rhombifolia L. & $\mathrm{X}$ & $\mathrm{X}$ & $X$ \\
\hline Cyperaceae & Cyperus rotundus L. & $\mathrm{X}$ & $\mathrm{X}$ & - \\
\hline Phyllantaceae & Phyllantus tenellus Roxb & $\mathrm{X}$ & $X$ & - \\
\hline Convolvulaceae & Ipomoea triloba $\mathrm{L}$. & $\mathrm{X}$ & - & - \\
\hline
\end{tabular}

$\mathrm{M}+\mathrm{F}$ con. $=$ castor beans + common bean intercrop; $\mathrm{M}$ mono $=$ castor bean monoculture; $\mathrm{F}$ mono $=$ common bean monoculture; $\mathrm{X}=$ presence; - = absence.

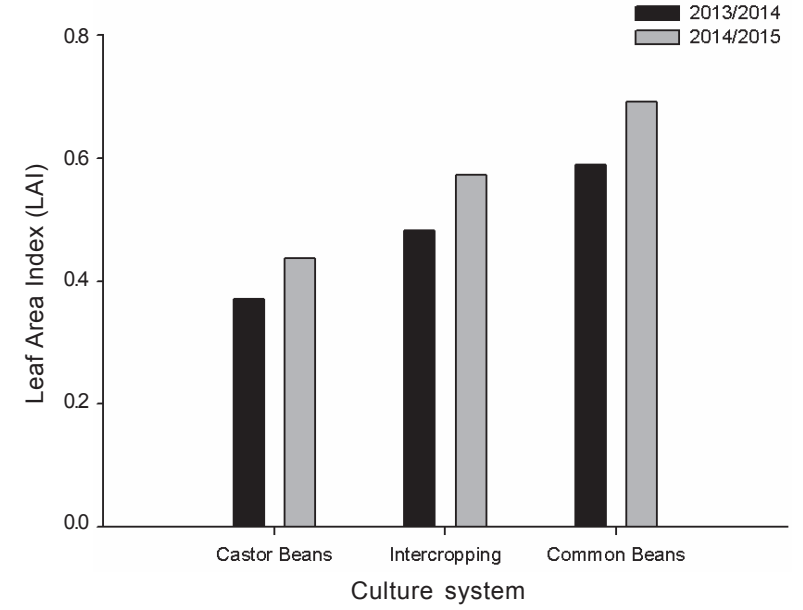

Figure 2 - Leaf area index (LAI) of weeds on castor bean and common bean intercropping systems and their respective monocultures, for the 2013/2014 and 2014/2015 crops in Ipameri-GO. UEG, Ipameri-GO, 2015. biomass had an intermediate accumulation. During both years in which the experiment was conducted, the greater accumulation occurred for the castor bean monoculture.

In relation to the common bean monoculture, during the first year, an intermediate accumulation occurred; during the second year, a lower accumulation occurred among the evaluated systems (Figure 2). This behavior is justified, since in intercrops, the presence of common beans in between castor bean rows, as well as on its monoculture, the high plant population in the area becomes a physical barrier, damaging the weeds on the area when it comes to the exposition to solar radiation, constituting in fact a competitive effect of the culture against weeds.

In the case of the castor bean monoculture, the incidence of solar radiation in weeds was higher, due to the greater spacing used for the culture, thus, favoring the weeds, above all, those belonging to the Poaceae family, which have a C4 metabolism and, therefore, that are more demanding in terms of luminosity (Taiz and Zeiger, 2013).

In addition, weeds have several strategies to adapt to environmental variations, and they may, under high light intensity, show a reduced leaf area expansion, thicker leaf blades and a pronounced layer of palisade cells. These strategies aim at protecting against the excess of radiation, in addition to concentrating higher amounts of protein on chloroplasts in order to support the greater electron flow (Concenço et al., 2014). This statement may justify the LAI variation (Figure 2) and the behavior of the dry biomass accumulation of weeds (Figure 3), which establishes a close relationship among these characteristics. 


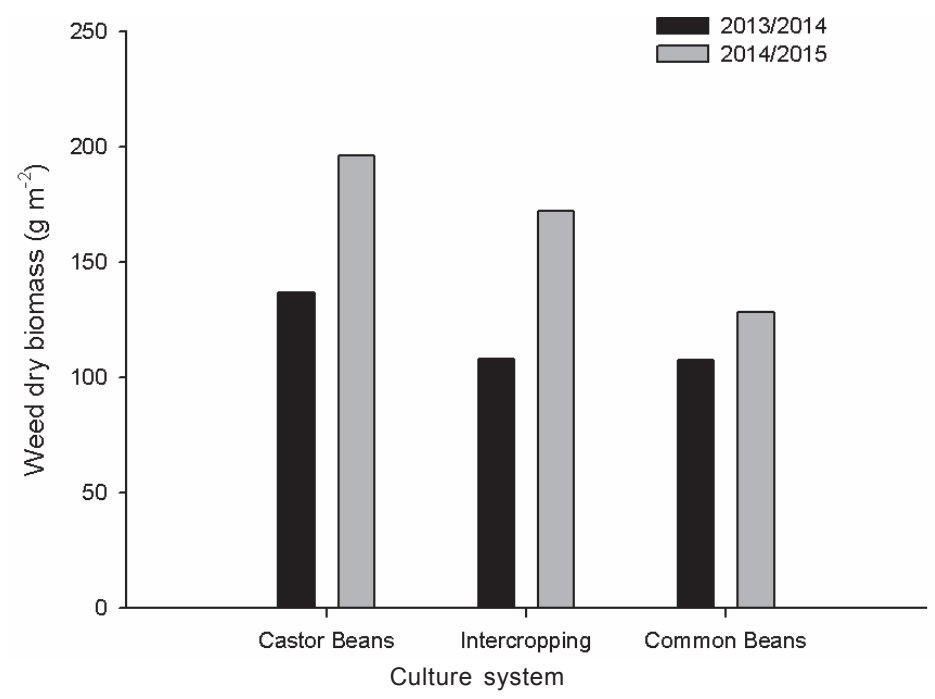

Figure 3 - Weed dry biomass accumulation on castor bean and common bean intercropping systems and their respective monocultures, on the 2013/2014 and 2014/2015 crops, in Ipameri-GO. UEG, Ipameri-GO, 2015.

\section{Survey and phytosociology of weeds}

\section{Castor bean culture}

During the second year of intercropping culture of castor beans and common beans, weeds showed a reduction on their density in relation to the first year of culture (Table 2).

In relation to the distribution pattern of infesting species, it is observed that during the agricultural year of 2014/2015, the coco-grass (Cyperus rotundus) and black-jack (Bidens pilosa) species showed changes, and they were no longer contagious (distributed throughout the entire area) and became randomized (occurring in dead spots), that is, they were sporadically found in the cultivated area. An opposite behavior was observed for the Benghal dayflower (Commelina benghalensis), which was found distributed across the entire culture area (contagious). This result shows that the management used to conduct the cultures during the previous year was not able to reduce the incidence of this species.

According to the importance value index (IVI) of the weeds seen on the castor bean and common bean intercrop during the first culture (Figure 4A), the main species found were: buffelgrass (Cenchrus echinatus), fireplant (Euphorbia heterophylla), Indian goosegrass (Eleusine indica) and joyweed (Alternanthera tenella). During the second culture (Figure 4B), a reduction of the IVI of buffelgrass occurred, due to the low relative dominance, with an increase of the relative density of fireplant, possibly due to the fact that this species propagates through seeds, and the herbicides used are not actually effective for their control.

This increase on the relative density probably favored the competition among weeds, which justifies the reduction on the relative dominance of buffelgrass, since this characteristic is related to the accumulation of dry biomass of the species. The increase on the relative density of fireplant on castor bean and common bean intercrops is a concern, since the species belongs to the same family as castor beans. This fact could make it harder to control it without affecting the main culture.

For the castor bean monoculture, as well as on the intercrop with common beans, the weed community showed similar behaviors, reducing the density values of plants during the second year of culture (Table 3). On monoculture, the main species found were joyweed, Indian goosegrass, brachiaria and buffelgrass, among which, joyweed showed a reduction on the relative density during the second culture in relation to the first one (Figure 5).

Joyweed is an herbaceous plant, with several branches, and a high capacity to promote soil coverage, taking roots through the contact of its nodes with the soil (Moreira and Bragança, 2010). According to Kissmann and Groth (1999), this plant has a C4 photosynthesis metabolism, 
Table 2 - Mean values of the survey and phytosociological parameters of weeds on the castor bean and common bean intercropping culture system, for the 2013/2014 and 2014/2015 crops, in Ipameri-GO. UEG, Ipameri-GO, 2015

\begin{tabular}{|c|c|c|c|c|c|c|c|}
\hline \multirow{2}{*}{ ID } & \multirow{2}{*}{ COD. } & \multirow{2}{*}{$\begin{array}{c}\text { PD } \\
{\left.\text { (plants } \mathrm{m}^{-2}\right)}\end{array}$} & \multirow{2}{*}{ DI } & \multirow{2}{*}{ VA } & RDE & $\mathrm{RC}$ & $\mathrm{RD}$ \\
\hline & & & & & \multicolumn{3}{|c|}{$(\%)$} \\
\hline \multicolumn{8}{|c|}{ Crop 2013/2014 } \\
\hline Fireplant & EPHHL & 42.55 & Contagious & 1253.18 & 34.67 & 12.12 & 22.52 \\
\hline Indian goosegrass & ELEIN & 14.72 & Contagious & 181.48 & 11.99 & 12.12 & 15.30 \\
\hline Joyweed & ALRTE & 8.95 & Contagious & 70.27 & 7.29 & 9.09 & 7.13 \\
\hline Arrowleaf sida & SIDRH & 0.69 & Randomized & 0.14 & 0.56 & 6.06 & 0.23 \\
\hline Coco-grass & CYPRO & 0.29 & Contagious & 0.66 & 0.23 & 3.03 & 2.10 \\
\hline Benghal dayflower & COMBE & 2.35 & Randomized & 1.39 & 1.91 & 12.12 & 4.53 \\
\hline Lilac tasselflower & EMISO & 0.81 & Randomized & 0.01 & 0.66 & 6.06 & 0.88 \\
\hline Buffelgrass & CCHEC & 45.74 & Contagious & 69.14 & 37.27 & 12.12 & 41.09 \\
\hline Common spiderwort & EPHHI & 1.12 & Contagious & 10.04 & 0.91 & 3.03 & 0.15 \\
\hline Stonebreaker & PYLTE & 0.565 & Contagious & 2.55 & 0.46 & 3.03 & 0.12 \\
\hline Common morning glory & IPOTR & 0.57 & Randomized & 0.00 & 0.46 & 6.06 & 1.26 \\
\hline Black-jack & BIDPI & 0.2875 & Contagious & 0.66 & 0.23 & 3.03 & 0.15 \\
\hline False buttonweed & BOILF & 0.62 & Contagious & 3.03 & 0.50 & 3.03 & 0.58 \\
\hline Brachiaria & BRADC & 3.48 & Contagious & 9.29 & 2.84 & 9.09 & 3.97 \\
\hline \multicolumn{8}{|c|}{ Crop 2014/2015 } \\
\hline Fireplant & EPHHL & 33.75 & Contagious & 1003.90 & 34.70 & 9.38 & 24.52 \\
\hline Indian goosegrass & ELEIN & 11.75 & Contagious & 119.37 & 12.08 & 12.50 & 18.74 \\
\hline Joyweed & ALRTE & 7.50 & Contagious & 49.60 & 7.71 & 9.38 & 8.35 \\
\hline Arrowleaf sida & SIDRH & 0.50 & Randomized & 0.27 & 0.51 & 6.25 & 0.08 \\
\hline Coco-grass & CYPRO & 0.25 & Randomized & 0.17 & 0.26 & 3.13 & 2.24 \\
\hline Benghal dayflower & COMBE & 2.00 & Contagious & 1.87 & 2.06 & 12.50 & 4.07 \\
\hline Lilac tasselflower & EMISO & 0.50 & Randomized & 0.27 & 0.51 & 6.25 & 0.81 \\
\hline Buffelgrass & CCHEC & 35.25 & Contagious & 449.10 & 36.25 & 12.50 & 33.12 \\
\hline Common spiderwort & EPHHI & 1.00 & Contagious & 2.67 & 1.03 & 3.13 & 0.08 \\
\hline Stonebreaker & PYLTE & 0.5 & Contagious & 0.67 & 0.51 & 3.13 & 0.04 \\
\hline Common morning glory & IPOTR & 0.5 & Randomized & 0.27 & 0.51 & 6.25 & 1.22 \\
\hline Black-jack & BIDPI & 0.25 & Randomized & 0.17 & 0.26 & 3.13 & 0.04 \\
\hline False buttonweed & BOILF & 0.50 & Contagious & 0.67 & 0.51 & 3.13 & 0.37 \\
\hline Brachiaria & BRADC & 3.00 & Contagious & 7.60 & 3.08 & 9.38 & 6.31 \\
\hline
\end{tabular}

$\mathrm{ID}$ - identification; $\mathrm{COD}=$ code; $\mathrm{PD}=$ plant density; $\mathrm{DI}=$ distribution; $\mathrm{VA}=$ variance; $\mathrm{RDE}=$ relative density; $\mathrm{RC}=$ relative constancy; $\mathrm{RD}=$ relative dominance

(A)

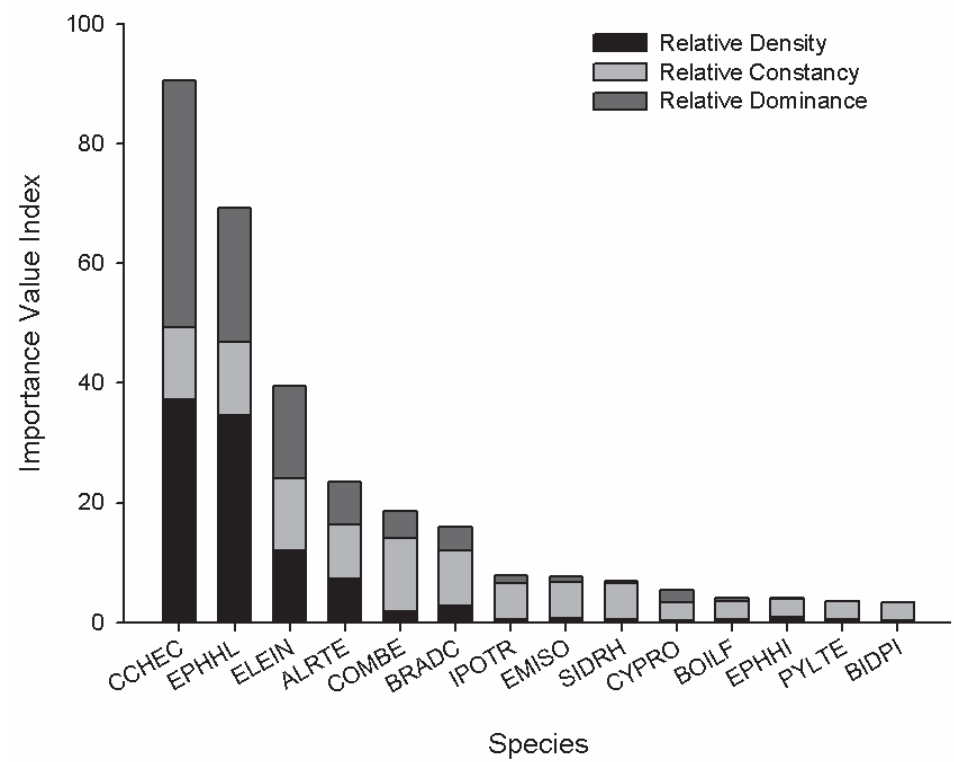

(B)

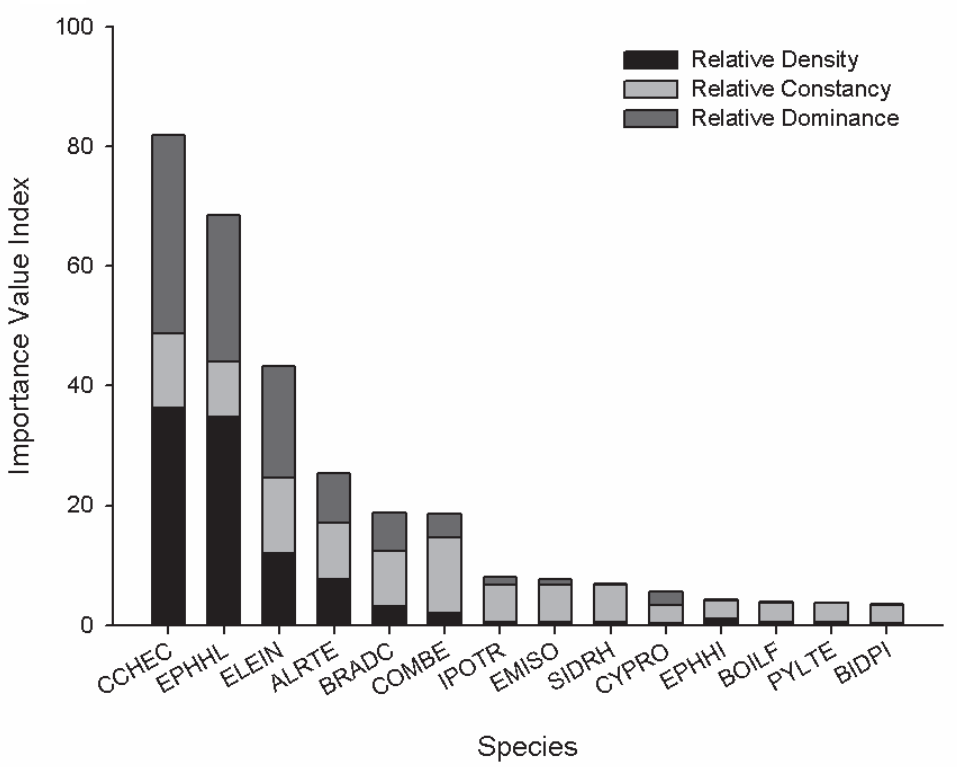

Figure 4 - Importance value index (IVI) of weed species on the castor bean and common bean intercropping system, for the 2013/2014 (A) and 2014/ 2015 (B) crops, in Ipameri-GO. UEG, Ipameri-GO, 2015. 
Table 3 - Mean values of the survey and phytosociological parameters of weeds on the castor bean monoculture system, for the 2013/2014 and 2014/2015 crops, in Ipameri. UEG, Ipameri-GO, 2015

\begin{tabular}{|c|c|c|c|c|c|c|c|}
\hline \multirow{2}{*}{ ID } & \multirow{2}{*}{ COD. } & PD & \multirow{2}{*}{ DI } & \multirow{2}{*}{ VA } & $\mathrm{RDE}$ & $\mathrm{RC}$ & $\mathrm{RD}$ \\
\hline & & (plants $\mathrm{m}^{-2}$ ) & & & \multicolumn{3}{|c|}{$(\%)$} \\
\hline \multicolumn{8}{|c|}{ Crop 2013/2014 } \\
\hline Fireplant & EPHHL & 1.23 & Randomized & 0.00 & 1.37 & 6.67 & 2.41 \\
\hline Indian goosegrass & ELEIN & 19.45 & Contagious & 352.04 & 21.79 & 20.00 & 28.61 \\
\hline Joyweed & ALRTE & 39.39 & Contagious & 44.26 & 44.13 & 20.00 & 26.31 \\
\hline Arrowleaf sida & SIDRH & 0.36 & Contagious & 1.05 & 0.41 & 3.33 & 3.90 \\
\hline Coco-grass & CYPRO & 7.61 & Contagious & 66.70 & 8.53 & 6.67 & 0.56 \\
\hline Benghal dayflower & COMBE & 1.00 & Randomized & 0.95 & 1.11 & 6.67 & 0.48 \\
\hline Lilac tasselflower & EMISO & 1.04 & Randomized & 0.66 & 1.16 & 6.67 & 3.19 \\
\hline Buffelgrass & CCHEC & 7.03 & Contagious & 68.45 & 7.87 & 6.67 & 13.02 \\
\hline Common spiderwort & EPHHI & 2.37 & Contagious & 44.94 & 2.66 & 3.33 & 1.41 \\
\hline Stonebreaker & PYLTE & 1.635 & Contagious & 21.39 & 1.83 & 3.33 & 0.33 \\
\hline Goat's head & ACNHI & 0.73 & Contagious & 4.26 & 0.82 & 3.33 & 2.56 \\
\hline Brachiaria & BRADC & 7.42 & Contagious & 55.90 & 8.31 & 13.33 & 17.22 \\
\hline \multicolumn{8}{|c|}{ Crop 2014/2015 } \\
\hline Fireplant & EPHHL & 0.50 & Contagious & 0.67 & 0.76 & 9.68 & 2.32 \\
\hline Indian goosegrass & ELEIN & 16.50 & Contagious & 280.40 & 25.19 & 19.35 & 30.03 \\
\hline Joyweed & ALRTE & 24.50 & Contagious & 99.47 & 37.40 & 19.35 & 26.55 \\
\hline Arrowleaf sida & SIDRH & 0.25 & Randomized & 0.17 & 0.38 & 3.23 & 0.05 \\
\hline Coco-grass & CYPRO & 6.25 & Contagious & 49.77 & 9.54 & 6.45 & 1.81 \\
\hline Benghal dayflower & COMBE & 0.75 & Contagious & 0.70 & 1.15 & 6.45 & 0.28 \\
\hline Lilac tasselflower & EMISO & 0.75 & Contagious & 0.70 & 1.15 & 6.45 & 2.98 \\
\hline Buffelgrass & CCHEC & 6.00 & Contagious & 48.40 & 9.16 & 6.45 & 14.18 \\
\hline Common spiderwort & EPHHI & 2 & Contagious & 10.67 & 3.05 & 3.23 & 1.30 \\
\hline Stonebreaker & PYLTE & 1.25 & Contagious & 4.17 & 1.91 & 3.23 & 0.23 \\
\hline Goat's head & $\mathrm{ACNHI}$ & 0.5 & Contagious & 0.67 & 0.76 & 3.23 & 2.79 \\
\hline Brachiaria & BRADC & 6.25 & Contagious & 35.77 & 9.54 & 12.90 & 17.48 \\
\hline
\end{tabular}

ID - identification; $\mathrm{COD}=$ code; $\mathrm{PD}=$ plant density; $\mathrm{DI}=$ distribution; $\mathrm{VA}=$ variance; $\mathrm{RDE}=$ relative density; $\mathrm{RC}=$ relative constancy; $\mathrm{RD}=$ relative dominance.

\section{(A)}

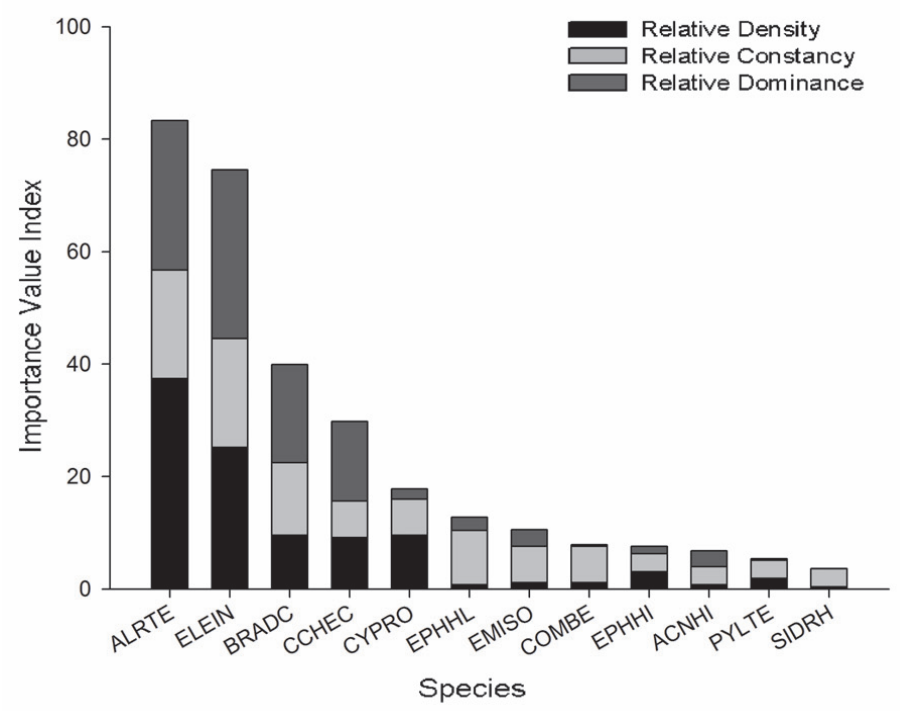

(B)

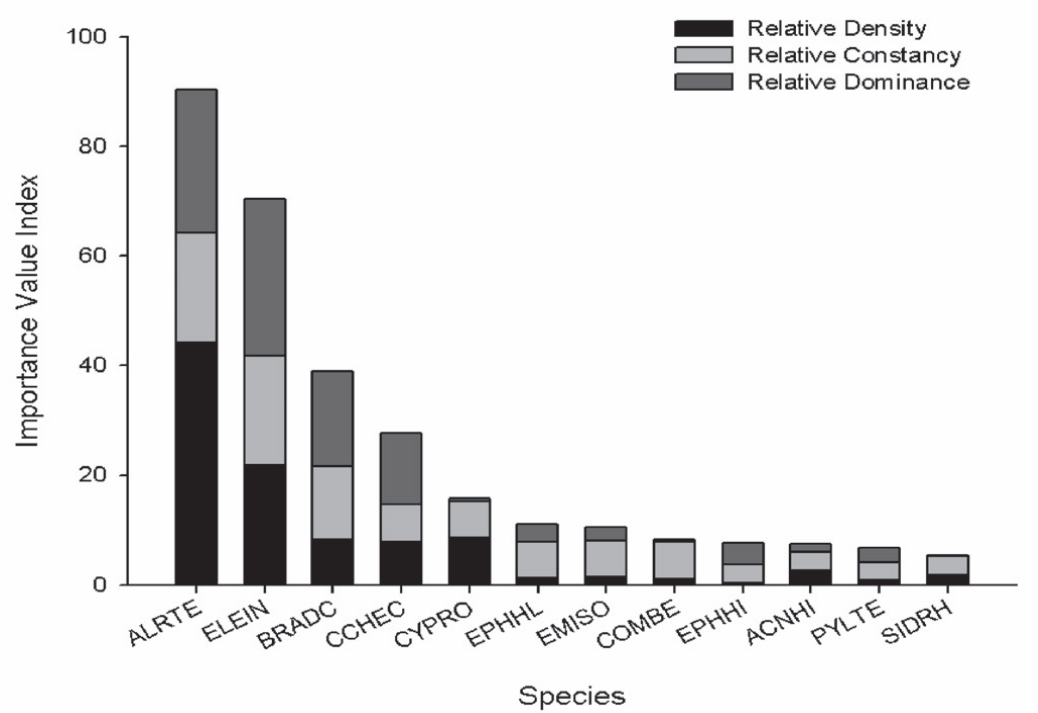

Figure 5 - Importance value index (IVI) of weed species on the castor bean monoculture system, for the 2013/2014 (A) and 2014/2015 (B) crops, in Ipameri-GO. UEG, Ipameri-GO, 2015. 
as well as most species that belong to the Poaceae family, which offers it competitive advantage when it occurs in crops of plants with C3 metabolism, such as is the case of castor beans and common beans. According to Canossa et al. (2007), the information on the control efficiency of A. tenella through the use of registered herbicides are limited; they also report an increase of the areas infested by this species, mainly on the grain production areas in the Brazilian cerrado.

Studies conducted by Canossa et al. (2008), investigating the germination process of joyweed, reported that the species germinates both in the presence and the absence of sunlight, however, its germination is favored by the presence of light and by higher temperatures. This fact may be the reason why only on castor bean monocultures the joyweed species stood out in terms of importance in relation to buffelgrass, since castor beans have a C3 photosynthesis cycle, with slow initial growth, which, allied to the spacing used $(3 \times 1 \mathrm{~m}$ in between the rows and between the plants), allowed a greater incidence of solar radiation on the soil, offering the temperature and luminosity for the species to germinate; on systems in which common bean was used, the presence of this culture promoted greater soil shading, contributing to a reduced sunlight incidence and, consequently, to a lower temperature.

Considering the distribution pattern of the species, during the first culture, the fireplant, Benghal dayflower and lilac tasselflower species were considered as randomized infestations; on the second culture, these species became contagious, and only arrowleaf sida was considered as randomized. Constantin et al. (2007), studying different species of arrowleaf sida, reported that the annual preparation of the soil (conventional soil preparation) minimizes the Sida rhombifolia infestation, and the species becomes perennial only on leveled curves or the borders of the crop, since they escape the mechanical work. This corroborates and justifies the fact that the species changed its distribution pattern between both evaluated crops, going from contagious to randomized during the second year.

\section{Common bean culture}

In general, on monocultures, a reduction was observed on the weed plant density on the area from one year to the other (Table 4), just as it was observed on intercropping systems involving castor bean and common bean cultures (Table 2) and on the castor bean monoculture (Table 3). Again, it was observed that arrowleaf sida showed a contagious condition, as observed for the castor bean monoculture (Table 3). As to Benghal dayflower, considered as a plant that is difficult to control, its status went from randomized to contagious. This fact was probably due to the inefficient control of the herbicides used. The fact that the intercrop offered greater soil coverage, above all by the common bean, possibly did not favor the proliferation of weeds, especially those with a $\mathrm{C} 4$ metabolism, in opposition to both castor bean and common bean monocultures. For this system, the reduced soil coverage generated by the canopy of cultivated plants favored the proliferation of weeds, causing them to change from a randomized condition to a contagious one, as it was the case for arrowleaf sida and Benghal dayflower on both studied crops.

As in the results obtained by Salgado et al. (2007), buffelgrass was the species with the highest relative constancy and density values in the infesting community for the common bean monoculture (Figure 6). Evaluating the interference of weeds on the common bean culture due to the spacing and sowing densities, Scholten et al. (2011) observed that the most frequent species found was buffelgrass, with density of approximately 60 plants per square meter at 10 DAE. These values are very close to the ones found on this paper on the cultures for the systems of common bean monoculture and intercrop with castor beans, which showed 52.3 and 26.35 plants per square meter for common bean monoculture on the 2013/2014 and 2014/2015 crops, respectively. Also according to these authors, the common bean culture, when planted with a spacing of $0.60 \mathrm{~m}$ between the rows at a density of 10 plants $\mathrm{m}^{-1}$, may coexist with this species for up to 19 days before they cause damages to the culture.

When compared to the IVI values of the common bean monoculture, it is observed that, although an approximate total value was shown, on the first crop, the component that contributed the most for this index was the relative dominance, showing that on the 2013/2014 crop, these plants accumulated a greater amount of dry biomass in comparison to the following crop. This behavior was opposed to what was shown by Indian goosegrass, which, on the second crop, had an increase on the dry biomass accumulation of weeds in relation to the previous crop. 
Table 4 - Mean values of the survey and phytosociological parameters of weeds on the common bean monoculture system, for the 2013/2014 and 2014/2015 crops, in Ipameri. UEG, Ipameri-GO, 2015

\begin{tabular}{|c|c|c|c|c|c|c|c|}
\hline \multirow{2}{*}{ ID } & \multirow[t]{2}{*}{ COD. } & $\mathrm{PD}$ & \multirow{2}{*}{ DI } & \multirow{2}{*}{ VA } & RDE & $\mathrm{RC}$ & $\mathrm{RD}$ \\
\hline & & $\left(\right.$ plants $\left.\mathrm{m}^{-2}\right)$ & & & \multicolumn{3}{|c|}{$(\%)$} \\
\hline \multicolumn{8}{|c|}{ Crop 2013/2014 } \\
\hline Fireplant & EPHHL & 13.24 & Contagious & 32.54 & 10.93 & 20.69 & 13.60 \\
\hline Indian goosegrass & ELEIN & 29.92 & Contagious & 152.34 & 24.70 & 10.34 & 28.75 \\
\hline Joyweed & ALRTE & 12.11 & Contagious & 22.80 & 10.00 & 10.34 & 5.40 \\
\hline Arrowleaf sida & SIDRH & 0.28 & Contagious & 0.21 & 0.23 & 3.45 & 0.15 \\
\hline False buttonweed & BOILF & 1.88 & Contagious & 9.43 & 1.55 & 3.45 & 2.22 \\
\hline Benghal dayflower & COMBE & 3.39 & Contagious & 30.65 & 2.80 & 3.45 & 4.62 \\
\hline Coatbutton & TRQPR & 0.58 & Randomized & 0.35 & 0.47 & 6.90 & 0.74 \\
\hline Lilac tasselflower & EMISO & 1.88 & Randomized & 0.01 & 1.55 & 10.34 & 4.25 \\
\hline Buffelgrass & CCHEC & 52.285 & Contagious & 373.63 & 43.16 & 17.24 & 25.83 \\
\hline Common spiderwort & EPHHI & 2.9325 & Contagious & 14.40 & 2.42 & 6.90 & 1.48 \\
\hline Brachiaria & BRADC & 2.645 & Contagious & 14.38 & 2.18 & 6.90 & 12.97 \\
\hline \multicolumn{8}{|c|}{ Crop 2014/2015 } \\
\hline Fireplant & EPHHL & 9.50 & Contagious & 61.07 & 14.96 & 13.04 & 13.66 \\
\hline Indian goosegrass & ELEIN & 12.50 & Contagious & 138.27 & 19.69 & 13.04 & 14.47 \\
\hline Joyweed & ALRTE & 5.00 & Contagious & 19.07 & 7.87 & 13.04 & 3.56 \\
\hline Arrowleaf sida & SIDRH & 0.25 & Randomized & 0.17 & 0.39 & 4.35 & 0.06 \\
\hline False buttonweed & BOILF & 1.50 & Contagious & 6.00 & 2.36 & 4.35 & 2.25 \\
\hline Benghal dayflower & COMBE & 2.75 & Contagious & 20.17 & 4.33 & 4.35 & 6.05 \\
\hline Coatbutton & TRQPR & 0.50 & Randomized & 0.27 & 0.79 & 8.70 & 0.62 \\
\hline Lilac tasselflower & EMISO & 0.50 & Randomized & 0.27 & 0.79 & 8.70 & 2.37 \\
\hline Buffelgrass & CCHEC & 26.25 & Contagious & 396.70 & 41.34 & 13.04 & 36.99 \\
\hline Common spiderwort & EPHHI & 2.5 & Contagious & 10.27 & 3.94 & 8.70 & 1.87 \\
\hline Brachiaria & BRADC & 2.25 & Contagious & 10.30 & 3.54 & 8.70 & 18.09 \\
\hline
\end{tabular}

ID - identification; $\mathrm{COD}=$ code; $\mathrm{PD}=$ plant density; $\mathrm{DI}=$ distribution; $\mathrm{VA}=$ variance; $\mathrm{RDE}=$ relative density; $\mathrm{RC}=$ relative constancy; $\mathrm{RD}=$ relative dominance.

(A)

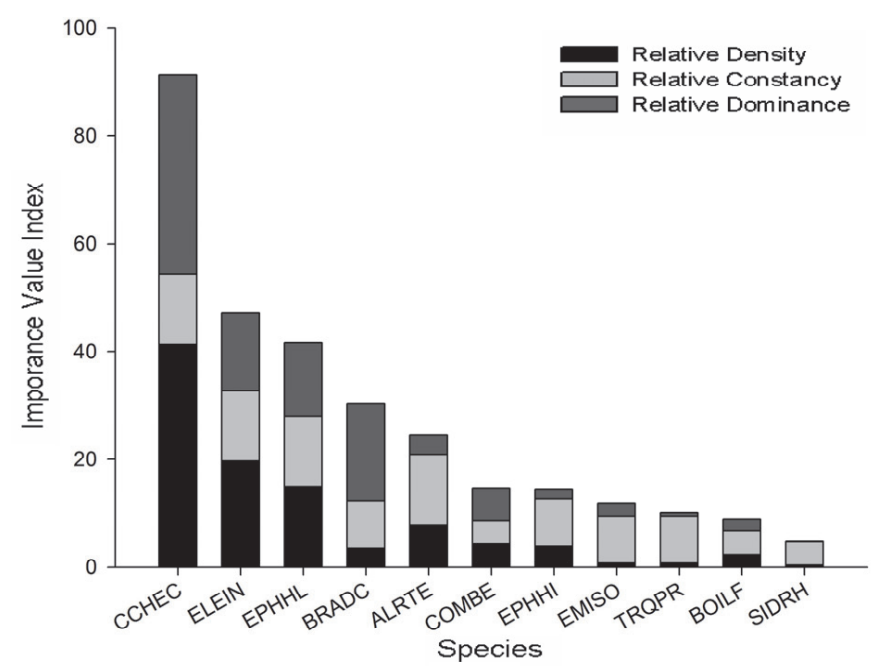

(B)

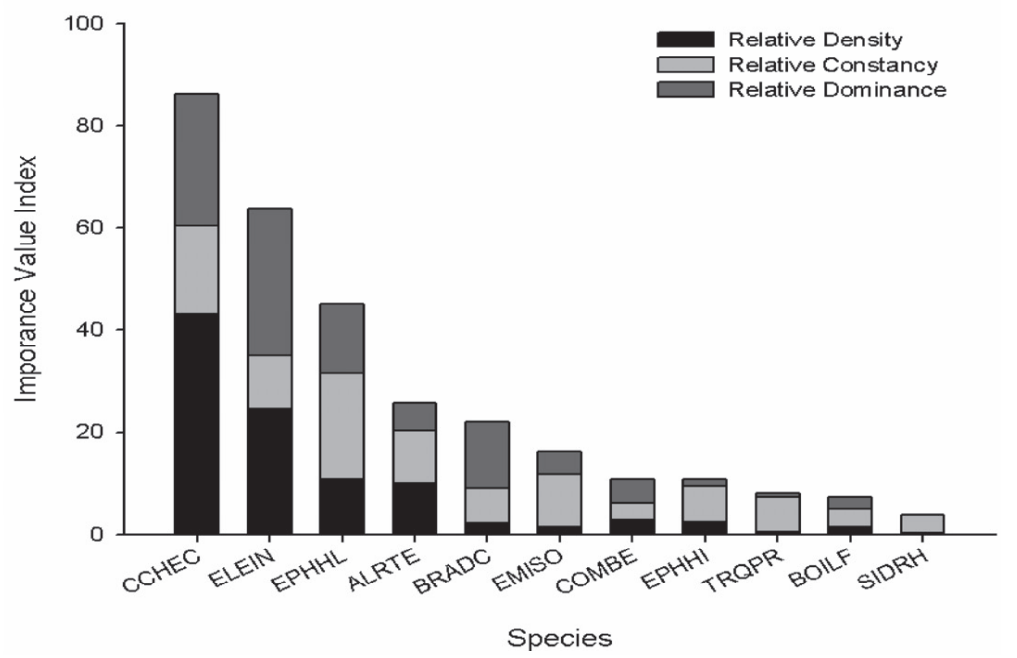

Figure 6 - Importance value index (IVI) of weed species on the common bean monoculture system, for the 2013/2014 (A) and 2014/2015 (B) crops, in Ipameri-GO. UEG, Ipameri-GO, 2015. 
For the three culture conditions, that is, for the castor bean and common bean intercrop and on castor bean and common bean monocultures, a prevalence of approximately $50 \%$ of narrowleaf species occurred, mainly for buffelgrass, Indian goosegrass and brachiaria. These results corroborate the reports by Ferreira et al. (2015) and Cobucci et al. (2004), which consider that on the "rainy" crops, the problems related to weeds are higher, especially due to the climatic conditions with high water availability, allied to the high incidence of solar radiation, which favors the development of plants with a $\mathrm{C} 4$ photosynthesis metabolism, as the species found on the situation shown herein.

An investigative paper on the damages caused by the weed community to the common bean monoculture in the Southeast region of Goiás, conducted by Teixeira et al. (2009), confirmed the hypothesis mentioned. These authors observed the prevalence of weeds from the brachiaria, buffelgrass, crabgrass and Indian goosegrass species. Pereira et al. (2015), in studies involving castor bean and common bean intercropping cultures, observed a greater dominance of narrowleaf weeds on the summer (rainy) crops, indicating brachiaria as the main infesting species under the conditions of the cerrado of Goiás, followed by coatbuttons (Tridax procumbens) and joyweed.

\section{Weed similarity index}

The similarity index (SI) compares the incidence of weed species on cultivated areas. Among the analyzed factors, SI shows a high similarity on the infesting flora of the different culture systems (Table 5). Similarity values above $25 \%$ indicate a high similarity among the factors compared by this index, according to the criterion established by Matteucci and Colma (1982). Hence, it could be observed that, on all culture systems, the index showed values above $70 \%$, indicating the similarity of the flora. This similarity across weed species on both crops may be explained by the similarity of the edaphoclimatic conditions, by the lack of an interval between the crops, by the management used to implement and conduct the crop in the area and by the fact that the survey was conducted when the cultivated plants were still small.

Table 5 - Similarity index across weeds on castor bean and common bean intercropping areas and their respective monocultures, in Ipameri-GO. UEG, Ipameri-GO, 2015

\begin{tabular}{|l|c|c|}
\hline \multicolumn{1}{|c|}{ Culture system } & Common beans & Castor beans \\
\hline Castor bean and common bean intercropping & 80.00 & 88.00 \\
\hline Castor bean monoculture & 78.26 & - \\
\hline Common bean monoculture & - & 78.26 \\
\hline
\end{tabular}

It is concluded that the most important weed species in the Southeast region of Goias on common bean and castor bean cultures are Cenchrus echinatus, Euphorbia heterophylla, Alternanthera tenella, Eleusine indica and Urochloa decumbens, which show a high similarity index across intercropping and monoculture culture methods for castor bean and common bean crops.

\section{ACKNOWLEDGEMENT}

To Foundation for Research Support of the State of Goiás (FAPEG) and CNPq, agencyies fosterer who gave support to this research.

\section{REFERENCES}

Azevedo D.M.P. et al. Controle de plantas daninhas. In: Azevedo D.M.P., Beltrão N.E.M., editores. O agronegócio da mamona no Brasil. $2^{\text {a }}$.ed. Campina Grande: Embrapa Algodão, 2007. p.333-59.

Braun-Blanquet, J. Fitossociologia. Bases para el estudio de las comunidades vegetales. Madrid: Blume, 1979. 
Canossa R.S. et al. Efetividade de herbicidas no controle de Alternanthera tenella. Rev Bras Herb. 2007;6:1-12.

Canossa R.S. et al . Temperatura e luz na germinação das sementes de apaga-fogo (Alternanthera tenella). Planta Daninha. 2008;26:745-50.

Cobucci T. Manejo e controle de plantas daninhas em feijão. In: Vargas L., Roman E.S. Manual de manejo e controle de plantas daninhas. Bento Gonçalves: Embrapa Uva e Vinho, 2004. p.453-80.

Constantin J. et al. Controle de diferentes espécies de guanxuma com aplicações seqüenciais de flumiclorac-pentil. Acta Sci Agron. 2007;29:475-80.

Concenço G. et al. Ciência das plantas daninhas: histórico, biologia, ecologia e físiologia. In: Monquero P.A., editor. Aspectos da biologia e manejo das plantas daninhas. São Carlos: RiMa, 2014. p.1-31.

Corrêa M.L.P. et al. Comportamento de cultivares de mamona em sistemas de cultivo isolados e consorciados com caupi e sorgo granífero. Ci Agron. 2006;37:200-7.

Cunha D.A. et al. Adubação fosfatada e produção de feijão-comum e mamona em consórcio. Biosci J. 2014;30:617-28.

Ferreira F.A. et al. Manejo de plantas daninhas. In: Carneiro J.E.S., Paula Júnior T.J., Borém A. Feijão. $2^{\mathrm{a}}$.ed. Viçosa, MG: Universidade Federal de Viçosa, 2015. p.207-41.

Fontes J.R.A. et al. Manejo de plantas daninhas nas culturas da palma-de-óleo e da mamona. In: Monquero P.A. Manejo de plantas daninhas nas culturas agrícolas. São Carlos: RiMa, 2014. p.209-32.

Kissmann K.G., Groth D. Plantas infestantes e nocivas. 2a.ed. São Paulo: BASF, 1999. 978p.

Lorenzi H. Manual de identificação e controle de plantas daninhas: plantio direto e convencional. $7^{\mathrm{a}}$.ed. Nova Odessa: Instituto Plantarum, 2014. 383p.

Matteucci S.D., Colma A. Metodología para el estudio de la vegetatión. Washington: OEA, 1982. 168p.

Monquero P.A. et al. Métodos de levantamento da colonização de plantas daninhas. In: Monquero P.A. Aspectos da biologia e manejo das plantas daninhas. São Carlos: RiMa, 2014. p.103-27.

Moreira H.J.C., Bragança H.B.N. Manual de identificação de plantas infestantes. Campinas: FMC, 2010. 326p.

Mueller-Dombois D., Ellenberg H. Aims and methods of vegetation ecology. New York: Wiley, 1974. 547p.

Odum E.P. Ecologia. Rio de Janeiro: Interamericana, 1985.

Oliveira A.R., Freitas S.P. Levantamento fitossociológico de plantas daninhas em áreas de produção de cana-de-açúcar. Planta Daninha. 2008;26:33-46.

Pereira F.S. et al. Agronomic performance of kidney bean and castor bean cultivars in intercropping and monocropping systems under weed competition. Austr J Crop Sci. 2015;9:614-20.

Pinheiro C., Chaves M. Photosynthesis and drought: can we make metabolic connections from available data. J Exper Bot. 2011;62:869-82.

Salgado T.P. et al. Interferência das plantas daninhas no feijoeiro carioca. Planta Daninha, 2007;25:443-8.

Scholten R. et al. Período anterior à interferência das plantas daninhas para a cultivar de feijoeiro 'Rubi' em função do espaçamento e da densidade de semeadura. Acta Sci Agron. 2011;33:313-20.

Taiz L., Zeiger E. Fisiologia vegetal. 5a.ed. Porto Alegre: Artmed, 2013.

Teixeira I.R. et al. Arranjos de plantas do feijoeiro-comum consorciado com mamona. Rev Caatinga. 2012;25:85-91.

Teixeira I.R. et al. Competição entre feijoeiros e plantas daninhas em função do tipo de crescimento dos cultivares. Planta Daninha. 2009;27:235-40.

Vieira C. Cultivos consorciados. In: Vieira C., Paula Júnior T.J., Borém A. Feijão. 2ª .ed. Viçosa, MG: UFV, 2006. p.493-528. 